\title{
Let Them Eat cake!
}

\author{
Audrey Samson \\ London, UK \\ a.samson@gre.ac.uk
}

\author{
Francisco Gallardo \\ London, UK \\ f.j.fernandezgallardo@qmul.ac. \\ uk
}

\author{
FRAUD \\ London, UK \\ else@fraud.la
}

\begin{abstract}
Let them eat cake! is a food-led event serving an edible imaginary of your Facebook profile. In early 2012, Facebook conducted massive scale emotional contagion by manipulating the emotional expressions in the News Feeds of 689,003 users [1]. This exemplifies how the governability and the biopolitics of everyday life flow through the many layers of shared images, liked videos, protocols, and hyperlinks, all orchestrated by the Facebook News Feed algorithm. Let them eat cake! proposes a gustatory experience to the visitor, a cake imagined with synthetic DNA encoded from a user's Facebook profile data. The profile's data categories (Ad Topics, Facial Recognition Data, Friends, Followers, Likes, and Political Views) are transposed into cake layers, with an absurd twist that reflects the algorithms agency. Ultimately the work explores innovative forms of engagement with humanmachine relationships through 'algorithm taste' interaction.
\end{abstract}

\section{Author Keywords}

Taste; interaction; algorithm; biopolitics; food art.

\section{ACM Classification Keywords}

J.5 [ARTS AND HUMANITIES]: fine arts, performing arts.

\section{General Terms}

Algorithms, Design, Experimentation.

\section{DESCRIPTION}

\section{Context}

"Let them eat cake!" she retorted, as she was told the peasants had no more bread to eat. According to the myth, the French Queen Marie-Antoinette was so detached from her subjects that she thought that they should simply eat a more luxurious foodstuff like cake if the staples had run out. The politics of power and their relationship to food are expressed in this well know phrase. Following Hannah Landecker's notion of food as a conditioning environment that shapes the activity of the genome and the physiology of the body[2], we use cake as exposure to social media politics. The designed and manufactured sets of molecules that compose food exist in the cloud in which we are immersed. Metabolism can be a source to understand circuits of exchange, in short, the biopolitics of matter.

The basis of these relationships depends on vast resources allocated to the development of new forms of data storage to accommodate expanding capacity requirements. Synthetic DNA is the proposed solution to the data storage problem. Its stable format, high-density information encoding capacity, and low maintenance properties are fueling the promise of near infinite, never-deprecating storage[3][4]. For the first time, data will be truly embodied, with the code of life itself. In short, DNA presages the Facebook server farms of the future.

Let them eat cake! looks particularly at some of the ways in which Facebook curates each News Feed. Such as: emotional contagion experiments[1], the augmentation of political polarization[5], and the adjustment of content visibility depending on its source, and its format[6][7]. We propose food-led events as a way to interact with these complex socio-technical assemblages. Though we do not yet propose the synthetic DNA version of the cake, but rather a harmless sugar substitute, we aim to emphasise the materiality of data by making it edible, and thereby to engage with the issues around near future DNA data storage and datafication through food-led interaction.

For CC2017, we present a local version of the cake in the form of the popular kueh lapis. This layered Peranakan desert - a marriage of Chinese and Malay cooking traditions following the influx of male Chinese traders in the 17 th Century - symbolises the complexity of human-machine relationships. With this submission, we propose tasting as a way to interact with these complex socio- technical assemblages, including DNA data storage, 'post-truth' and Facebook engineered news. 


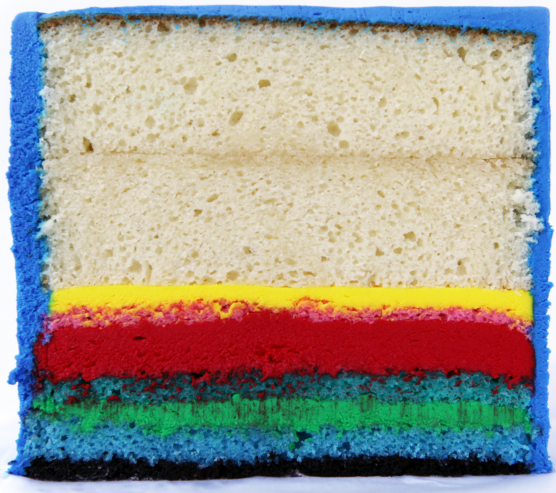

Figure 1 - Cross-section of the cake showing layers that correspond to the Facebook data categories.

\section{ARTIST PROFILE}

\section{Bio}

FRAUD is a duo (Audrey Samson + Francisco Gallardo) of media and spatial thingkers. Their backgrounds include computational culture, critical technical practices, postcolonial and critical feminism, performance, design and space system engineering. They develop forms of critical art-led inquiry into the multiples scales of power, and governability that flow through physical and cultural landscapes. Their practice is currently focused on exploring forms of slow violence and death embedded in, for instance, the entanglement between archiving practices and technical objects, the diminishing negantropism of global trade, systems of production after erasure, and alluring myths of ecological cosmopolitanism.

\section{REFERENCES}

1. Kramer, A. D. I., Guillory, J. E. and Hancock, J. T. 2014. 'Experimental Evidence Of Massive-Scale Emotional Contagion Through Social Networks'. Proceedings Of The National Academy Of Sciences 111 (24): 8788-8790.

2. Landecker, H. 2011. 'Food as exposure: Nutritional epigenetics and the new metabolism'. BioSocieties 6(2): 167-194.

3. Goldman, N., Bertone, P., Chen, S., Dessimoz, C., LeProust, E.M., Sipos, B., and Birney, E. 2013.

'Towards Practical, High-Capacity, Low-Maintenance Information Storage in Synthesized DNA'. Nature 494 (7435): 77-80.

4. Samson, A. and Gallardo F. 2015. "“Let Them Eat cake!!", She Said'. The Forager (5). http://www.theforagermagazine.com/5/4.

5. Bakshy, E., Messing, S., and Adamic, L. A. 2015. 'Exposure To Ideologically Diverse News And Opinion On Facebook'. Science 348 (6239): 1130-1132.

6. Welch, B., and Zhang, X. 2014. 'News Feed FYI: Showing Better Videos'.

https://newsroom.fb.com/news/2014/06/news-feed-fyishowing-better-videos/.

7. Pariser, E. The Filter Bubble: How the New Personalized Web Is Changing What We Read and How We Think. New York, NY, Penguin. 